\title{
An inventory of saprophagous Calyptratae (Insecta: Diptera) in urban green spaces of Buenos Aires City
}

\author{
Luciano D. PATITUCCI ${ }^{1,2^{*}}$, Pablo R. MULIERI ${ }^{1,2}$, M. Cecilia DOMÍNGUEZ $^{1,3}$ \& Juan C. \\ MARILUIS $^{1,2}$ \\ ${ }^{1}$ Consejo Nacional de Investigaciones Científicas y Técnicas, Buenos Aires, Argentina. ${ }^{2}$ Museo Argentino \\ de Ciencias Naturales "Bernardino Rivadavia", Av. A. Gallardo 470, C1405DJR, Buenos Aires, Argentina. \\ ${ }^{3}$ Laboratorio de Entomología, Instituto Argentino de Investigaciones de Zonas Áridas (IADIZA), CCT-Mendoza. \\ *Corresponding author, e-mail: lpatitu@yahoo.com.ar
}

\begin{abstract}
The biodiversity inventory is an urgent task for insect conservation. Particularly, the urban green spaces (non-built-up areas) within urban environments are a fundamental element to the maintenance and restoration of biodiversity. We describe the diversity of saprophagous Calyptratae in three urban green spaces: a private garden, an urban park, and a natural reserve in Buenos Aires City, Argentina, and we compare the presence of native and cosmopolitan species. A total of 14,688 specimens were collected, representing 62 species. The flies were captured by netting them on attractive baits, rotten viscerae of chicken and dog faeces. The three most abundant species, Cochliomyia macellaria, Tricharaea (Sarcophagula) occidua, and Chrysomya albiceps, represent $81.70 \%$ of the total sample. Native species represented a $67.24 \%$ of the total sample and presented an increase in terms of richness in larger and less modified spaces. Cosmopolitan species treated as "global homogenizers" were identified.
\end{abstract}

Key words: biodiversity, inventory, Calyptratae, Buenos Aires.

Resumen: Inventario de los Calyptratae (Insecta: Diptera) saprófagos en los espacios verdes urbanos de la ciudad de Buenos Aires. El inventario de la biodiversidad es una tarea urgente para la conservación de los insectos. En particular, los espacios verdes urbanos (áreas sin edificaciones) dentro de entornos urbanos son un elemento fundamental para el mantenimiento y restauración de la biodiversidad. Se describe la biodiversidad de los Calyptratae saprófagos en tres espacios verdes urbanos: un jardín privado, un parque urbano, y una reserva natural en la Ciudad de Buenos Aires, Argentina, y se compara la presencia de especies cosmopolitas y nativas. Un total de 14.688 especímenes fueron colectados, representando 62 especies. Las moscas fueron capturadas con red de mano sobres cebos de atracción, vísceras de pollo en descomposición y heces caninas. Las tres especies más abundantes, Cochliomyia macellaria, Tricharaea (Sarcophagula) occidua, y Chrysomya albiceps, representan el 81,70 \% de la muestra total. Las especies nativas representan 62,24\% de la muestra total y muestran un incremento en términos de riqueza en espacios más grandes y menos modificados. Se identificaron las especies cosmopolitas tratadas con "homogenizadores globales".

Palabras claves: Biodiversidad, inventario, Calyptratae, Buenos Aires.

\section{INTRODUCTION}

The biodiversity inventory is an urgent task for insect conservation, because many species are rapidly becoming extinct worldwide and our knowledge about them is scanty (Kim, 1993; Samways, 2005). Particularly, urbanization has severe effects on insect communities, resulting in decreased species richness (McKinney, 2008), or changes in the composition of species assemblages (Smith et al., 2006a). The modification of environments by humans is responsible for the introduction of an increasing number of species to new regions, where urban ecosystems provide opportunities to non-native (or alien) species to become established. Consequently, these non-native species affect various ecosystem characteristic, often competing with or preying on native species (Denys \& Schmidt, 1998; McIntyre, 2000; Schowalter, 2006). In this context, the remaining and usually isolated green spaces (non-built-up areas) within urban environments are funda- 
mental elements to the maintenance and restoration of the biodiversity (Smith et al. 2006b; Goddard et al. 2009).

Calyptratae are an adequate target group for monitoring biodiversity since they are the major lineage of higher Diptera in terms of richness and diversity of ecological traits (Brown et al. 2010; Pape et al. 2011). This taxon contains a large and diversified assemblage of saprophagous species, with several groups recognized as the most abundant organic matter-consumers in urban environments. Among them, some species have medical and veterinary impact due to their injurious interactions with humans and domestic animals as myiasis producers; or indirectly, due to their affinities to faeces or decomposing organic matter present in human settlements, thereby being potential mechanical vectors of diseases (Greenberg, 1973). For these reasons, knowledge of ecology and distribution of the necrophagous and coprophagous species provides a positive impact in urban insect studies, as well as in veterinary or biomedical fields.

The Metropolitan Area of Buenos Aires in Argentina is one of the largest urban agglomerations in South America and includes the capital of the country, Buenos Aires City. This city has approximately 250 urban green spaces (UGS), including public parks, sports fields, derelict land, the edges of roads, railways, waterways, squares and a natural reserve (AABA, 2010). Because it is surrounded by a large urbanized area, the UGS located in Buenos Aires City represent true isolated patches of unpaved surface. These patches have different types of vegetation cover. Previous studies on the urban entomofauna of Diptera in UGS of this city focused on aquatic immatures (Quiroga et al. 2013; Rubio et al. 2013) or on the study of assemblages of particular taxa (Calliphoridae or Sarcophagidae) inhabiting an urban natural reserve ("Reserva Ecológica Costanera Sur") (Mariluis et al. 2007; Mulieri et al. 2006; 2008). On the contrary, little attention has focused on other types of green spaces of the city. Hence, the diversity of saprophagous communities inhabiting a wide range of urban green spaces of Buenos Aires City remains largely undocumented.

The aim of the present work is to provide an inventory of the saprophagous Calyptratae present in urban green spaces in Buenos Aires City, focusing specially on the coprophagous and necrophagous species. This work describes and compares the presence of native and cosmopolitan species, and provides a reliable species database of the studied area.

\section{MATERIAL AND METHODS}

\section{Study areas}

Buenos Aires city is located on the western shore of the estuary of the Río de la Plata, and the samples were conducted in three UGS (Private Garden, Urban Park, and Natural Reserve) selected to monitoring saprophagous Calyptratae. These UGS were chosen taking into account that they represent different types of green spaces, with different degrees of human intervention: an intensively managed area (Private Garden), a moderately managed area (Urban Park), and a semi-natural area (Natural Reserve).

The Private Garden (PG) is located in the southern area of the city consisting in the garden of the Institute "Dr. Carlos G. Malbrán"

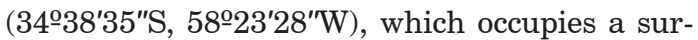
face of 4 ha. This green space is surrounded by residential buildings, factories and hospitals as well as small gardens with lawns and trees pruned regularly. The streets surrounding the Institute are paved and heavy traffic flows through them. The experimental field of the University of Buenos Aires was considered as Urban Park

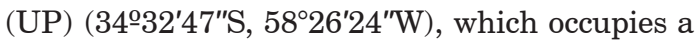
surface of 80 ha. This UGS is substantially larger than PG; its vegetation is more abundant with trees with occasional pruning regimes and extensive areas of grassland. In addition the site has some spaced buildings surrounded by paved streets with significant vehicular traffic and has the presence of farm animals (horses and poultry) as well as some beehives used for research. Finally, the environment considered Natural Reserve (NR) (34ํㅡㄴ $\left.53^{\prime \prime} \mathrm{S}, 58^{\circ}{ }^{\circ} 20^{\prime} 57^{\prime \prime} \mathrm{W}\right)$ was the "Reserva Ecológica Costanera Sur", located in the southeast of Buenos Aires City over the banks of the Rio de la Plata. This area was refilled with demolition materials from a road construction which took place during the 1970's, and it has rapidly evolved towards a semi-natural ecosystem. The reserve covers approximately 350 ha with different environments such as grassland, forests, and lakes with floating vegetation.

\section{Sampling methods and specimen preserva- tion}

Sampling methods for saprophagous dipterous are based mainly on captures made on attractive baits (Mulieri et al. 2011; Patitucci et al. 2011). We used two kinds of baits: $250 \mathrm{~g}$ of chicken viscera ( 5 days aged at ambient temperature) and $250 \mathrm{~g}$ of dog faeces (from a single dog, fed with dry dog food). These two types of baits 
can be considered representative of the decaying organic matter naturally present in the city (dog faeces, small vertebrate carcasses). Samples were taken monthly from May 2007 to April 2008, at each urban green space (PG, UP, NR) (totalizing 36 samples). Seven hourly events of capture of adult flies (10:00 - 16:00) were made with a hand net on each bait. The sampling effort was the same at each UGS. The baits were separated by $30 \mathrm{~m}$ from each other. The baits were exposed for 15 minutes to allow flies to arrive, and then all the arrived flies were captured by net. After each capture the baits were preserved in closed containers until the next capture. All baits were placed on the ground in green areas at the three UGS.

Specimens were killed in glass vials with carbon tetrachloride and then stored in the field in labelled envelopes for further study in the laboratory. The specimens collected were counted and identified to generic or specific level using appropriate keys (Shannon \& Del Ponte, 1926; Mariluis \& Schnack, 2002; Domínguez, 2007; Mulieri et al. 2010; Olea \& Mariluis, 2013; Patitucci et al. 2013; Domínguez \& Aballay, 2014). Voucher specimens are housed in "Instituto Argentino de Investigaciones de las Zonas Áridas", Mendoza, Argentina (IADIZA); and "Museo Argentino de Ciencias Naturales "Bernardino Rivadavia" (MACN)", Buenos Aires, Argentina.

\section{Data analysis}

In order to describe the assemblage of saprophagous Calyptratae, we estimated richness and abundance. Assemblage dominance was analysed with range-abundance curves for the three UGS (Krebs, 1999). Rare species were quantified and are defined as species represented only by one specimen in assemblages (singletons) (Novotny \& Basset, 2000).

We classified the species of saprophagous Calyptratae into two groups according to the actual distribution of species: Cosmopolitan species (species present in more than one biogeographic region), and native species (species present only in the Neotropical Region). This classification was based on the information obtained from specialized literature on the species (James, 1970; Pont, 1974; Pape, 1996; Carvalho et al. 2003; Carvalho et al. 2005).

Contingency tables were used to examine both the number of species (richness) and total number of individuals (frequency) for the following categorical variables: UGS type (PG, UP, NR) and distribution group of species (cosmopolitan or native). We applied the Chi square analysis to test whether the frequency of each group is independent of the UGS type. When richness was analysed, the number of species was small and did not fit with the conditions necessary for the application of the chi-square test. In this case the Fisher exact test was applied (Freeman \& Halton, 1951). A critical level of $\alpha$ of $P=0.05$ was used in testing all statistical hypotheses.

Non parametric Spearman rank correlations were used to examine the relationship between the richness of both distribution groups. Similar correlation analyses were applied to examine the relationship between the abundance and the richness of each distribution group with temperature, respectively.

\section{RESULTS}

A total of 14,688 specimens of Calyptratae Diptera, representing 62 species, were collected. The most abundant family was Calliphoridae with 12,201 specimens (83.07\%), followed by Sarcophagidae with 1,728 specimens (11.76\%), Muscidae with 348 specimens (2.37\%), Fanniidae with 252 specimens (1.72\%), and Anthomyiidae with 159 specimens (1.08\%). The highest percent of the collected specimens was observed at NR $(44.70 \%)$, decreasing towards smaller and intensively managed green spaces, as UP (36.02\%) and PG (19.27\%). The three most abundant species, Cochliomyia macellaria (Calliphoridae) with 9,713 specimens, Tricharaea (Sarcophagula) occidua with 1,178 specimens (Sarcophagidae), and Chrysomya albiceps (Calliphoridae) with 1,109 specimens, represent $81.70 \%$ of the total assemblage (Appendix 1). The Sarcophagidae was the family with the highest number of species $(38.71 \%)$, followed by Muscidae (27.42\%), Calliphoridae (16.13\%), Fanniidae (12.90\%), and Anthomyiidae (4.84\%). The highest richness was observed at NR (80.65\%), decreasing towards UP (67.74\%) and PG (59.68\%). Only six species were collected as singletons (9.67\% of total richness), 3 species of Fanniidae (Fannia albitarsis, Fannia canicularis, Fannia scalaris), 1 Muscidae (Ophyra albuquerquei), and 2 Sarcophagidae (Blaesoxipha sp. and Microcerella sp.) (Table 1).

The slopes of the three curves of rankabundance presented similar evenness profiles. Species of Calliphoridae and Sarcophagidae were dominant at the three UGS, while Muscoidea species (Anthomyiidae + Fanniidae + Muscidae) increased their relative abundance towards larger areas, which are intrinsically more diverse. 
Table 1. Richness of Anthomyiidae, Calliphoridae, Fanniidae, Muscidae and Sarcophagidae recorded in three urban green spaces in Buenos Aires City, Argentina. Acronyms: $\mathrm{PG}=$ private garden; UP = urban park; $\mathrm{NR}=$ natural reserve.

\begin{tabular}{lccccc}
\hline & PG & UP & NR & $\begin{array}{c}\text { Total } \\
\text { Richness }\end{array}$ & $\begin{array}{c}\text { Single- } \\
\text { tons }\end{array}$ \\
\hline Anthomyiidae & 2 & 2 & 3 & 3 & 0 \\
Calliphoridae & 9 & 9 & 9 & 10 & 0 \\
Fanniidae & 5 & 6 & 6 & 8 & 3 \\
Muscidae & 11 & 9 & 13 & 17 & 1 \\
Sarcophagidae & 10 & 16 & 19 & 24 & 2 \\
Total Richness & 37 & 42 & 50 & 62 & - \\
Singletons & 2 & 2 & 2 & - & 6 \\
\hline
\end{tabular}

Cochliomyia macellaria, T. (S.) occidua, and C. albiceps dominated the sample in the three UGS and represent the $75-85 \%$ of the specimens collected. Lucilia sericata presented higher abundance in PG (10.74\% of total assemblage) and decreases in UP $(0.79 \%)$ and NR $(0.26 \%)$, while Lucilia cluvia increased towards less managed areas $(\mathrm{PG}=0.99 \% ; \mathrm{UP}=1.21 \% ; \mathrm{NR}=4.13 \%$ of total assemblage). Oxysarcodexia paulistanensis presented a similar abundance in the three UGS, while Sarcophaga (Bercaea) africa was collected only in PG. On the other hand, two Muscoidea species, Fannia tumidifemur and Ophyra aenescens, were dominant in NR $(1.52 \%$ and $1.87 \%$ of total catch respectively) and decreased towards more managed green spaces (UP $=0.77 \%$; $\mathrm{PG}=0.70 \%$ and $\mathrm{UP}=0.30 \% ; \mathrm{PG}=0.27 \%$ of total catch respectively) (Fig. 1).

\section{Cosmopolitan vs. native species}

Considering the three UGS, the total richness showed that $67.24 \%(n=39)$ of species were natives. The native species presented a slight increase towards less modified spaces (PG: $\mathrm{n}=21$, $55.26 \%$; UP: $\mathrm{n}=29,72.50 \%$; NR: $\mathrm{n}=34,70.34$ $\%$, while the richness of cosmopolitan species was higher in PG (PG: $n=17,44.74 \%$; UP: $n=11$, $27.50 \%$; NR: $\mathrm{n}=14,29.17 \%)$. Despite this trend, the differences in proportional richness of cosmopolitan and native species between the UGS were no significant (Fisher Exact Probability Test: $\left.\mathrm{X}_{(\mathrm{N}=126, \mathrm{df}=2)}=3.21 ; \mathrm{P}=0.2\right)$. Thus, in term of richness the relative proportion of both groups of species was similar in the different UGS.

Shared species between the three UGS represent $40.32 \%$ of the total richness (25 species).

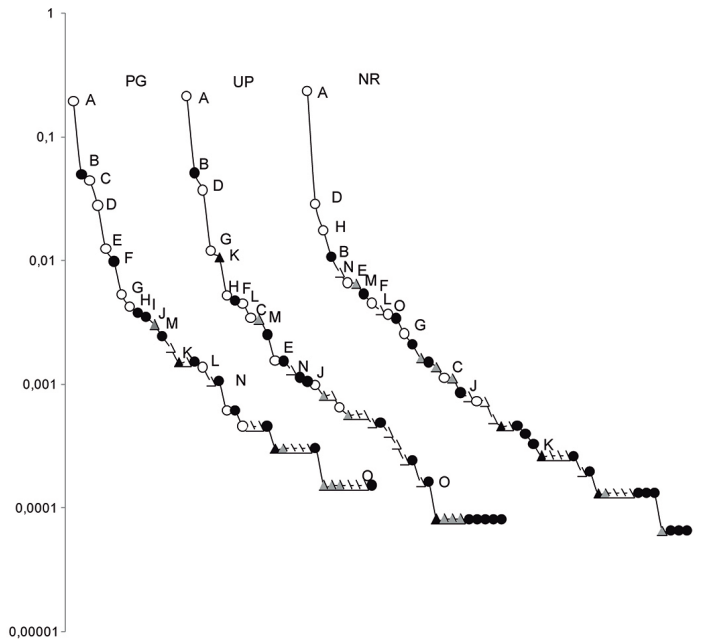

Fig. 1. Rank-abundance curves in the PG, UP, and NR in Buenos Aires City, Argentina. Acronyms: PG $=$ private garden; UP = urban park; $\mathrm{NR}=$ natural reserve. $\mathrm{A}=$ C. macellaria $; \mathrm{B}=$ Tricharaea $(S$.) occidua; $\mathrm{C}=$ L. sericata $; \mathrm{D}=C$. albiceps $; \mathrm{E}=C$. vicina $; \mathrm{F}=O$. paulistanensis $; \mathrm{G}=$ C. megacephala $; \mathrm{H}=$ L. cluvia $; \mathrm{I}=$ $S$. (B.) africa; $\mathrm{J}=R$. sueta; $\mathrm{K}=H$. punctipennis; $\mathrm{L}=S$. chlorogaster $; \mathrm{M}=$ F. tumidifemur $; \mathrm{N}=\mathrm{O}$. aenescens; $\mathrm{O}$ $=P$. pampiana . White circle $=$ Calliphoridae; black circle $=$ Sarcophagidae; white triangle $=$ Muscidae; black triangle $=$ Anthomyiidae; grey triangle $=$ Fanniidae .

Nine cosmopolitan species (47.36\% of this group) and sixteen native species ( $41.02 \%$ of this group) were captured at the three UGS, respectively. Both groups (cosmopolitan and native) were dominated by Calliphoridae and Sarcophagidae species (Appendix 1, Fig. 2).

The ratio (relative number of individuals) between cosmopolitan and native specimens showed significant differences between the different UGS ( $\mathrm{X} 2=254.94 ; \mathrm{P}<0.001)$. Even though the whole sample contained $84.49 \%$ of native specimens, this percentage showed a stepwise increase in spaces with less environmental management. (PG: $74.9 \%$; UP: $85.74 \%$; NR: $87.63 \%$ ).

Records of monthly richness for cosmopolitan and native species presented positive correlation in each UGS (PG: $\mathrm{R}=0.82, P<0.01$; UP: $\mathrm{R}=0.89, P<0.01$; NR: $\mathrm{R}=0.75, P<0.01$ ). The richness fluctuation for cosmopolitan and native species was similar in the three UGS, with lower values during winter (Jul-Aug) followed by an increase during the spring. Higher richness of native species was observed during the whole year in NR and UP (Fig. 3). Correlations between temperatures and abundance of flies was positive and significant only for native species at the three 
Cosmopolitan species

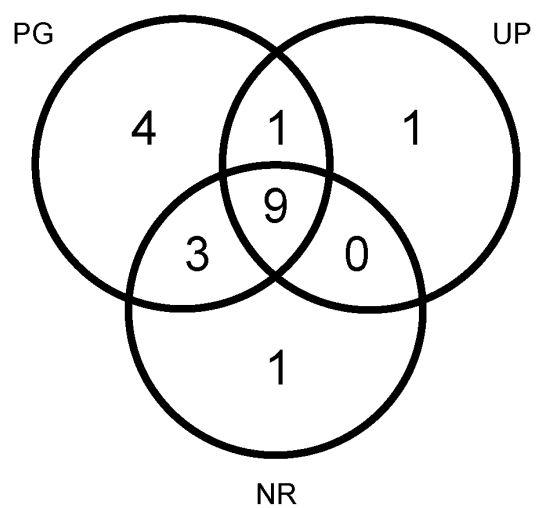

Native species

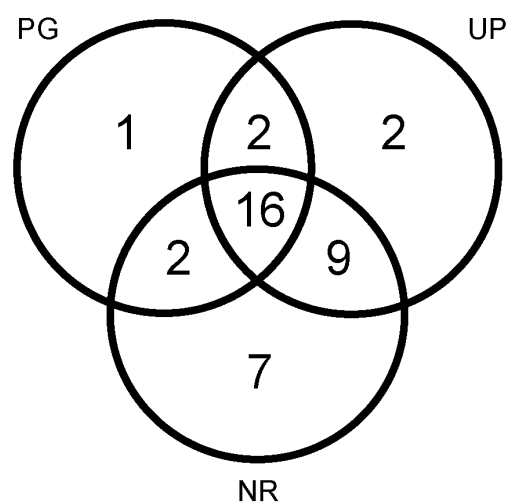

Fig. 2. Species overlap among three UGS. Acronyms: PG = private garden; UP = urban park; NR = natural reserve.

UGS (PG: $\mathrm{r}=0.72, \mathrm{P}<0.01$; UP: $\mathrm{r}=0.84, \mathrm{P}<$ 0.01 ; NR: $\mathrm{r}=0.88, \mathrm{P}<0.01$ ). On the other hand, richness showed positive and significant correlations with temperatures in two cases only, for cosmopolitan species in NR $(\mathrm{r}=0.77, \mathrm{P}<0.01)$ and for native species in UP $(r=0.78, \mathrm{P}<0.01)$.

\section{DISCUSSION}

While there are isolated works on some families of saprophagous Calyptratae in urban green spaces in Argentina (Centeno et al. 2004; Schnack et al. 1995), this study is the first report which includes all saprophagous Calyptratae families highlighting the composition of the species present in urban landscapes of Buenos Aires city. The results obtained not only allow for a better understanding of regional diversity and distribution of saprophagous Calyptratae, but also provide reliable estimates of richness and proportion of native and cosmopolitan species present in a community associated to highly urbanized areas. The sampling techniques strongly affect the result of biodiversity surveys. Accordingly, an important consideration for the community here studied is that the type of baits used has biased the sampling over those saprophagous species attracted to substrates with a high content of animal protein, such as faeces and carrion. The results obtained highlight that the faeces attract significantly more Sarcophagidae than the viscerae, and the opposite trend is observed for Calliphoridae.

The surveyed community was largely dominated by species belonging to Oestroidea (Calliphoridae + Sarcophagidae) with higher abundance of Calliphoridae. On the contrary,
Muscoidea families represented approximately $5 \%$ of the total assemblage. The dominance pattern observed can depend on two main possible explanations: the reproductive potential and the differences on bait attractiveness for the different taxa. As was observed in previous studies, Calliphoridae was the most abundant family in saprophagous communities (Linhares, 1981; Patitucci et al. 2011), probably because blowflies are the first to find and colonize vertebrate remains (Vargas \& Wood, 2010). In addition, calliphorids can lay larger number of eggs per female on carrion. On the contrary, a lower reproductive potential is detected for Sarcophagidae and Muscidae. In the case of Sarcophagidae their ovoviviparity provides advantages in the use of ephemeral substrates, allowing a rapid start in resource exploitation, but at the cost of a lower number of larvae produced per female (Hanski, 1987a). On the other hand, the species of Muscoidea may be attracted to other kinds of substrates (decaying vegetation, living plant tissue, or aquatic detritus) that were not evaluated in this work. The low abundance of the saprophagous Muscoidea could be due to competition with other oviparous flies (as the calliphorids), that could act as a limiting factor in terms of the access to the ephemeral resources and their disadvantage relative to number of eggs per clutch (Hanski, 1987a). Also, some Muscoidea are not true necrophagous or coprophagous species; these species (e.g. species recorded as singletons), may act as "tourists" on the baits because they could be attracted to the humidityon the surface of the baits, or as predators of other diptera (Carvalho \& Mello-Patiu, 2008). 

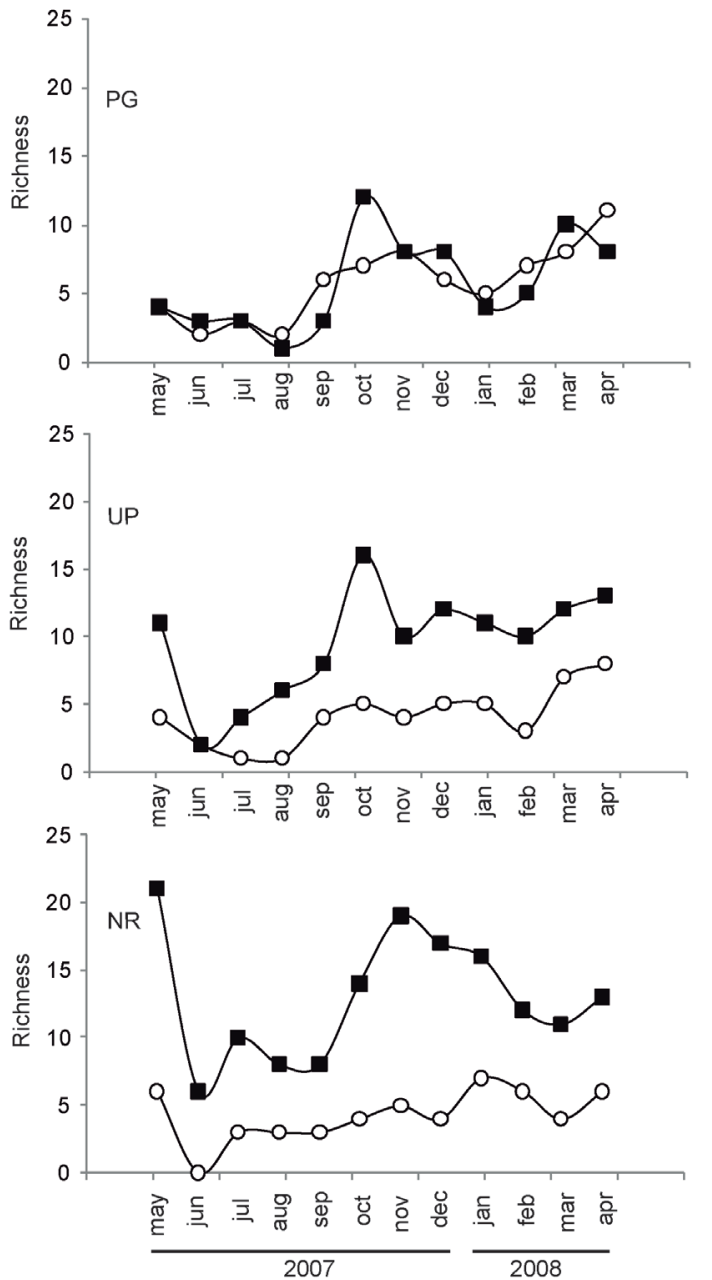

Fig. 3. Monthly richness fluctuation between cosmopolitan and native species in the three UGS $(\mathrm{PG}=$ private garden; UP = urban park; NR = natural reserve). Black square: native species; white circle: cosmopolitan species.

Saprophagous communities exploiting small and patchy ephemeral resources are dominated by few species (Hanski, 1987b). The results obtained here for each urban green space showed similar results, and exhibited a similar geometric series pattern of species abundance indicating a low species diversity and equitability, with more than $85 \%$ of total specimens belonging to three species only: C. macellaria, C. albiceps (Calliphoridae) and T. (S.) occidua (Sarcophagidae). Several studies establish that the increasing intensity of urban activity causes an increase in non-native species and a decrease in native species (Denys \& Schmidt, 1998; McIntyre, 2000). The coexistence of C. macellaria (native) and Ch. albiceps (non-native) has been treated in some previous studies. Preceding studies (Baumgartner
\& Greenberg, 1984; Mariluis \& Schnack, 1986; Battán-Horestein et al. 2007) have proposed that declination in abundance of $C$. macellaria in South America is due to the presence of $C$. albiceps, a facultative predator of necrophagous calliphorid larvae. On the contrary, Koller et al. (2011), Mulieri et al. (2006) observed that the presence of Chrysomya species did not seem to play a major role in the abundance of $C$. macellaria. These authors suggested that the greater abundance of $C$. macellaria relative to $C$. albiceps is related to scarcely disturbed environments or natural areas and not to the interspecific competition or predation. Nevertheless, our findings of high prevalence of $C$. macellaria at the three green areas inside an urban matrix, suggest that the modification of the natural environment cannot disrupt populations of this native species. The abundance of T. (S.) occidua was also observed in previous studies (Mulieri et al. 2008; 2011). This coprophilous native species may be successfully colonizing human-modified environments because it may act as a dung exploiter of domestic animals, as dog faeces, presumably the most common available breeding media in urban landscapes.

Richness is partially related with scale, since larger areas are richer because there is generally greater heterogeneity. This contributes to the species-area relationship predicted by island biogeographic theory (MacArthur and Wilson 1967). Therefore, comparing richness among landscapes that vary in size can be problematic. More than $70 \%$ of the native species collected exclusively in NR belong to Muscoidea. On the other hand, only $25 \%$ of cosmopolitan species collected exclusively in PG belong to this superfamily. This observation is in agreement with the findings of other authors (Carvalho et al. 1984; Uribe et al. 2010). Even the size of the patches may be also influencing, we observed an increase in terms of richness and abundance of native Muscoidea species in less managed environments.

The three sampled urban green spaces studied here share a large fraction of species, probably because these habitats provide similar resources, such as feeding or breeding substrates. The high richness observed for Sarcophagidae and Muscidae is related to the presence of several coprophilous species. Particularly, the close association between humans and dogs in accordance with the growth in population densities in urban environments produce large amounts of dog faeces in public spaces (Mikovic et al. 2009). Consequently, the highly available dog faeces 
in urban areas may promote the maintenance of large numbers of coprophilous flies, regardless of the habitat characteristics of the different urban green areas. Another reason for the large fraction of species shared between urban green spaces could be the strong flying ability of Calyptratae, which allows them to colonize substrates. As an example, a female blowfly carrying eggs can detect the presence of carcasses over a remarkably large distance (Erzinçlioglu, 1996), or across natural or artificial barriers (MacLeod \& Donnelly, 1960).

Synanthropic species are well adapted to intensely-modified urban environments wherever humans construct across the planet (McKinney, 2002). These species take advantage of food resources provided by humans, and colonize cities around the world, and they can attain population densities far above those found under natural conditions (McKinney, 2006). The presence of cosmopolitan species such as Calliphora vicina, Musca domestica, S. (B.) africa, in intensely modified habitats at the urban core could be associated with the food resources provided and the biotic homogenization around the world (McKinney, 2006). Also, these synanthropic species considered as "global homogenizers" can be found in other cities of South America (Ferreira, 1979; Carvalho et al. 1984; Figueroa-Roa \& Linhares, $2002 ; 2004)$. The potential value of urban green spaces for enhancing biodiversity has been recognized (Goddard et al. 2009). Also, this kind of environment could provide refuge for these species, and hence can contribute to conservation of biodiversity in urban environments (MacIvor \& Lundholm, 2010) as remnant patches of suitable habitat or as green corridors to facilitate species dispersal within the urban matrix in a megalopolis (Vergnes et al. 2012).

\section{ACKNOWLEDGEMENTS}

The authors are very grateful to Arício X. Linhares, to an anonymous referee, and to the editor, Arturo Roig Alsina for their invaluable comments and suggestions. We thank "Reserva Ecológica Costanera Sur" administration, and all the staff of the experimental field of FCENUBA. This work was supported by CONICET and FONCyT grant PICT 2011 №0490.

\section{BIBLIOGRAPHY}

AABA [Internet]. c2004-2009. Argentina: Buenos Aires: Atlas Ambiental de Buenos Aires; [updated
2010 Dec 31; cited 2014 Dec 09]. Available from: http://www.atlasdebuenosaires.gov.ar"

Battán-Horestein, M., A.X. Linhares, B. Rosso \& M.D. Garcia. 2007. Species composition and seasonal succession of saprophagous calliphorids in a rural area of Córdoba, Argentina. Biol. Res. 40 (2): $163-171$.

Baumgartner, D.L. \& B. Greenberg. 1984. The genus Chrysomya (Diptera: Calliphoridae) in the New World. J. Med. Entomol. 21 (1): 105-113.

Brown, B.V., A. Borkent, J. M. Cumming, D. M. Wood, N. E. Woodley \& M. Zumbado. 2010. Manual of Central American Diptera, Volume 2. National Research Council of Canada Press, Canada, 1142 pp.

Carvalho, C.J.B. de, J.R. Almeida \& C.B. de. Jesús. 1984. Dípteros sinantrópicos de Curitiba e arredores (Paraná, Brasil). I. Muscidae. Rev. Bras. Entomol. 28 (4): 551-560.

Carvalho, C.J.B. de, A.C. Pont, M.S. Couri \& D. Pamplona. 2003. A catalogue of the Fanniidae (Diptera) of the Neotropical Region. Zootaxa. 219: 1-32.

Carvalho, C.J.B. de, M.S. Couri, A.C. Pont, D. Pamplona \& S.M. Lopes. 2005. A Catalogue of the Muscidae (Diptera) of the Neotropical Region. Zootaxa. 860: 1-282.

Carvalho, C.J.B. de \& C.A. de Mello-Patiu. 2008. Key to the adults of the most common forensic species of Diptera in South America. Rev. Bras. Entomol. 52 (3): 309-406.

Centeno, N., Almorza, D., \& C. Arnillas. 2004. Diversity of Calliphoridae (Insecta: Diptera) in Hudson, Argentina. Neotrop. Entomol. 33 (3): 387-390.

Denys, C. \& H. Schmidt. 1998. Insect communities on experimental mugwort (Artemisia vulgaris L.) plots along an urban gradient. Oecologia, 113: 269277.

Domínguez, M.C. 2007. A taxonomic revision of the Southern South American species of the genus Fannia Robineau-Desvoidy (Diptera: Fanniidae). Pap. Avulsos Zool. 47 (24): 289-347.

Domínguez, M.C. \& F.H. Aballay. 2014. An updated key to the species of Fannia Robineau-Desvoidy (Diptera: Fanniidae) of Southern South America, and the description of a new species from Mendoza, Argentina. Zootaxa. 3795 (2): 152-160

Erzinçlioglu, Z. 1996. Blowflies. The Richmond Publishing Press, Cambridge, 306 pp.

Ferreira, M.J. de M. 1979. Sinantropia de dípteros muscoideos de Curitiba. II: Sarcophagidae. Rev. Bras. Biol. 39 (4): 773-781.

Freeman, G.H. \& J.H. Halton.1951. Note on exact treatment of contingency, goodness of fit and other problems of significance. Biometrika. 38 (1-2):141149.

Figueroa-Roa, L. \& A.X. Linhares. 2002. Sinantropia de los Calliphoridea (Diptera) de Valdívia, Chile. Neotrop. Entomol. 31(2): 233-239.

Figueroa-Roa, L. \& A.X. Linhares.2004. Synantropy of Muscidae (Diptera) in the City of Valdivia, Chile. Neotrop. Entomol. 33 (5): 647-651. 
Goddard, M.A., A.J. Dougill \& T.G. Benton. 2009. Scaling up from gardens: biodiversity conservation in urban environments. Trends Ecol. Evol. 25: 9098

Greenberg, B. 1973. Flies and Disease, Volume 1. Princeton Press, USA, 856 pp.

Hanski, I. 1987a. Nutritional ecology of dung-and carrion-feeding insects. In: Slansky, F.\& J.G. Rodriguez (eds.), Nutritional Ecology of Insects, Mites, Spiders, and Related Invertebrates, pp. 837884. John Wiley \& Sons Press, USA.

Hanski, I. 1987b. Carrion fly community dynamics: patchiness, seasonality and coexistence. Ecol. Entomol. 12 (3): 257-266.

James, M.T. 1970. A catalogue of the Diptera of the Americas South of the United States. Family Calliphoridae. Mus. Zool. Univ. São Paulo. 102: $1-28$.

Koller, W.W., A.T. Medeiros de Barros \& E.C. Corrêa. 2011. Abundance and seasonality of Cochliomyia macellaria (Diptera: Calliphoridae) in Southern Pantanal, Brazil. Rev. Bras. Parasitol. Vet. 20 (1): 27-30.

Kim, K.C. 1993. Biodiversity, conservation and inventory: why insects matter. Biodivers. Conserv. 2: 191-214.

Krebs, C.J. 1999. Ecological methodology. AddisonWesley Educational Press, USA. 620 pp.

Linhares, A.X. 1981. Synantropy of Calliphoridae and Sarcophagidae (Diptera) in the city of Campinas, São Paulo, Brazil. Rev. Brasil. Entomol. 25 (3): 189215.

MacIvor, J.S. \& J. Lundholm. 2010. Insect species composition and diversity on intensive green roofs and adjacent level-ground habitats. Urban Ecosyst. 14: 225-241.

MacArthur, R. H. \& E. O. Wilson. 1967. The theory of island biogeography (Vol. 1). Princeton University Press. 203pp.

MacLeod, J. \& J. Donnelly. 1960. Natural features and blowfly movement. J Anim Ecol. 29 (1): 85-93

Mariluis, J.C. \& J.A. Schnack.1986. Ecología de una taxocenosis de Calliphoridae del área platense (Provincia de Buenos Aires) (Insecta, Diptera). Ecosur 12/13: 81-91.

Mariluis, J.C. \& J.A. Schnack. 2002. Calliphoridae de la Argentina. Sistemática, ecología e importancia sanitaria (Diptera, Insecta). En: O. S. Salomón. (ed.), Actualizaciones en Artropodología Sanitaria Argentina, pp 23-37. Fundación Mundo Sano, Buenos Aires, Argentina.

Mariluis, J.C., J.A. Schnack, P.R. Mulieri \& J.P. Torretta. 2007. The Sarcophagidae (Diptera) of the Coastline of Buenos Aires City, Argentina. J. Kans. Entomol. Soc. 80 (3): 243-251.

McIntyre, N.E. 2000. Ecology of urban arthropods: a review and a call to action. Ann. Entomol. Soc. Am. 93: 825-835.

McKinnney, M.L. 2002. Urbanization, Biodiversity, and Conservation. BioScience. 52: 883-890.

McKinney, M.L. 2006. Urbanization as a major cause of biotic homogenization. Biol. Cons. 127: 247-260.
Mc Kinney, M.L. 2008. Effects of urbanization on species richness: A review of plants and animals. Urban Ecosyst. 11:161-176.

Milkovic, M., Carbajo, A.E. \& D. Rubel. 2009. Spatial distribution of canine faeces in Buenos Aires suburbs: implications for public health. Area. 41: 310318.

Mulieri, P.R., J.C. Mariluis \& L.D. Patitucci LD. 2010. Review of the Sarcophaginae (Diptera: Sarcophagidae) of Buenos Aires Province (Argentina), with a key and description of a new species. Zootaxa. 2575: 1-37.

Mulieri, P.R., L.D. Patitucci, J.A. Schnack \& J.C. Mariluis. 2011. Diversity and seasonal dynamics of an assemblage of Sarcophagidae (Diptera) in an urbanized gradient in Buenos Aires, Argentina. J. Insect Sci. 11: 1-15.

Mulieri, P.R., J.A. Schnack, J.C. Mariluis \& J.P. Torretta JP. 2008. Flesh flies species (Diptera: Sarcophagidae) from a grassland and a woodland in a Nature Reserve of Buenos Aires, Argentina. Rev. Biol. Trop. 56 (3): 1287-1294.

Mulieri, P.R., J.P. Torretta, J.A. Schnack \& J.C. Mariluis. 2006. Calliphoridae (Diptera) of the coastline of Buenos Aires, Argentina: species composition, numerical trends, and bait's preferences. Entomol. News. 117 (2): 139-147.

Novotny, V. \& Y. Basset. 2000. Rare species in communities of tropical insect herbivores: Pondering the mystery of singletons. Oikos. 89: 564-572.

Olea, M.S. \& J.C. Mariluis. 2013. The genus Calliphora (Diptera: Calliphoridae) in Argentina, with the first records of C. lopesi Mello 1962. Rev. Soc. Entomol. Argent. 72 (1): 99-104

Pape, T. 1996. Catalogue of Sarcophagidae of the world (Insecta: Diptera). Mem. Entomol. Intern. 8: $1-558$.

Pape, T., V. Blagoderov, M.B. Mostovski \& B. Mikhail. 2011. Order Diptera Linnaeus, 1758. In: Z. Q. Zhang, (ed.), Animal biodiversity: An outline of higher-level classification and survey of taxonomic richness. Zootaxa. 3148: 222-229.

Patitucci, L.D., P.R. Mulieri, M.S. Olea \& J.C. Mariluis. 2013. Muscidae (Insecta: Diptera) of Argentina: revision of Buenos Aires province fauna, with a pictorial key to species. Zootaxa. 3702: 301-347.

Patitucci, L.D., P.R. Mulieri, J.A. Schnack \& J.C. Mariluis. 2011. Species composition and heterogeneity of blowflies assemblages (Diptera: Calliphoridae) in urban-rural gradients at regional scale in Argentinean Patagonia. Stud. Neotrop. Fauna Environ. 46 (1): 49-58.

Pont, A.C. 1974. A catalogue of the dipteral of the Americas South of the United States. Family Anthomyiidae. Mus. Zool. Univ. São Paulo. 96a: 1-21.

Quiroga, L., S. Fischer \& N. Schweigmann. 2013. Immature mosquitoes associated with urban parklands: Implications for water and mosquito management. J. Am. Mosq. Contr. Assoc. 29 (1): 27-32.

Rubio, A., M.I. Bellocq, \& D. Vezzani. 2013. Macro- and microenvironmental factors affecting tyre-breed- 
ing flies (Insecta: Diptera) in urbanised areas. Ecol. Entomol. 38 (3): 303-314.

Samways, M.J. 2005. Insect diversity conservation. Cambridge Press, United Kingdom, 342 pp.

Schnack, J.A., J. Mariliuis, N. Centeno \& J. Muzón. 1995. Composición específica, ecología y sinantropía de Calliphoridae (Insecta: Diptera) en el Gran Buenos Aires. Rev. Soc. Entomol. Argent. 54 (1-4): 161-171.

Schowalter, T. D. 2006. Insect Ecology. An Ecosystem Approach. Academic Press, London, 576 pp.

Smith, R.M., P.H. Warren, K. Thompson \& K.J. Gaston. 2006a. Urban domestic gardens (VI): environmental correlates of invertebrate species richness. Biodivers. Conserv. 15: 2415-2438.

Smith, R.M., K.J. Gaston, P.H. Warren \& K. Thompson. 2006b. Urban domestic gardens (VIII): environmental correlates of invertebrate abundance.
Biodivers. Conserv. 15: 2515-2545.

Shannon, R.C. \& E. Del Ponte. 1926. Sinopsis parcial de los Muscoideos Argentinos. Rev. Inst. Bacteriol., Buenos Aires. 4: 549-590.

Uribe, M.N., M. Wolf \& C.J.B. de Carvalho. 2010. Synanthropy and ecological aspects of Muscidae (Diptera) in a tropical dry forest ecosystem in Colombia. Rev. Bras. Entomol. 54 (3): 462-470.

Vargas, J. \& M.D. Wood. 2010. Calliphoridae (blow flies). In: Brown, B.V., A. Borkent, J.M. Cumming, M.D. Wood, N.E. Woodley \& M.A. Zumbado (eds.), Manual of Central American Diptera. Volumen 2, pp.1297-1304, National Research Council of Canada Press, Canada.

Vergnes, A., I. Le Viol \& P. Clergeau. 2012. Green corridors in urban landscapes affect the arthropod communities of domestic gardens. Biol. Conserv. 145 (1): 171-178. 
Appendix 1. Species list and number of specimens of Anthomyiidae, Calliphoridae, Fanniidae, Muscidae and Sarcophagidae collected in three urban green spaces in Buenos Aires City, Argentina. Status: $\mathrm{c}=$ cosmopolitan; $\mathrm{n}=$ native. Acronyms: $\mathrm{PG}=$ private garden; $\mathrm{UP}=$ urban park; $\mathrm{NR}=$ natural reserve; $\mathrm{F}=$ faeces; $\mathrm{CV}=$ chicken viscera. **Argentina, new record; *Buenos Aires province, new record.

\begin{tabular}{|c|c|c|c|c|c|c|c|c|}
\hline \multirow[t]{2}{*}{ Family } & \multirow[t]{2}{*}{ Species } & \multirow[t]{2}{*}{ Status } & \multicolumn{2}{|c|}{ PG } & \multicolumn{2}{|c|}{ UP } & \multicolumn{2}{|c|}{ NR } \\
\hline & & & $\mathrm{CV}$ & $\mathrm{F}$ & $\mathrm{CV}$ & $\mathrm{F}$ & $\mathrm{CV}$ & $\mathrm{F}$ \\
\hline \multirow[t]{3}{*}{ Anthomyiidae } & Delia platura (Meigen, 1826) & $\mathrm{c}$ & 0 & 2 & 0 & 0 & 0 & 2 \\
\hline & $\begin{array}{l}\text { Hylemyia punctipennis Shannon \& Del Ponte, } \\
1926\end{array}$ & $\mathrm{n}$ & 1 & 9 & 14 & 119 & 0 & 4 \\
\hline & Pegomya bruchi (Shannon \& Del Ponte, 1926) & $\mathrm{n}$ & 0 & 0 & 0 & 1 & 0 & 7 \\
\hline \multirow[t]{10}{*}{ Calliphoridae } & Calliphora lopesi Mello 1962 & $\mathrm{n}$ & 2 & 2 & 7 & 1 & 11 & 0 \\
\hline & Calliphora vicina Robineau-Desvoidy 1830 & c & 59 & 24 & 14 & 5 & 84 & 17 \\
\hline & Chrysomya albiceps (Wiedemann, 1819) & $\mathrm{c}$ & 187 & 1 & 472 & 0 & 449 & 0 \\
\hline & Chrysomya megacephala (Fabricius, 1784) & $\mathrm{c}$ & 35 & 0 & 149 & 0 & 39 & 0 \\
\hline & Cochliomyia hominivorax (Coquerel, 1858) & $\mathrm{n}$ & 0 & 0 & 12 & 0 & 55 & 1 \\
\hline & Cochliomyia macellaria (Fabricius, 1775) & $\mathrm{n}$ & 1562 & 33 & 3279 & 111 & 4493 & 235 \\
\hline & Lucilia cluvia (Walker, 1849) & $\mathrm{n}$ & 21 & 7 & 21 & 43 & 132 & 139 \\
\hline & Lucilia cuprina (Wiedemann, 1830) & $\mathrm{c}$ & 0 & 3 & 0 & 0 & 0 & 0 \\
\hline & Lucilia sericata (Meigen, 1826) & $\mathrm{c}$ & 173 & 131 & 21 & 21 & 9 & 8 \\
\hline & Sarconesia chlorogaster (Wiedemann, 1831) & $\mathrm{n}$ & 8 & 1 & 40 & 15 & 50 & 19 \\
\hline \multirow[t]{8}{*}{ Fanniidae } & Euryomma carioca Albuquerque, $1956 * *$ & $\mathrm{n}$ & 1 & 0 & 0 & 1 & 1 & 16 \\
\hline & Fannia albitarsis Stein, 1911 & $\mathrm{c}$ & 0 & 0 & 0 & 0 & 1 & 0 \\
\hline & Fannia canicularis (Linnaeus 1761) & $\mathrm{c}$ & 0 & 0 & 0 & 1 & 0 & 0 \\
\hline & Fannia femoralis (Stein 1898) & $\mathrm{n}$ & 1 & 1 & 6 & 4 & 17 & 8 \\
\hline & Fannia losgateados Domínguez 2007 * & $\mathrm{n}$ & 0 & 0 & 5 & 2 & 20 & 1 \\
\hline & Fannia sanihue Dominguez \& Aballay, 2008 * & $\mathrm{n}$ & 1 & 0 & 1 & 0 & 2 & 0 \\
\hline & Fannia scalaris (Fabricius,1794) & $\mathrm{c}$ & 1 & 0 & 0 & 0 & 0 & 0 \\
\hline & Fannia tumidifemur Stein, 1911 & $\mathrm{n}$ & 13 & 7 & 25 & 16 & 88 & 12 \\
\hline \multirow[t]{15}{*}{ Muscidae } & Graphomyia auriceps Malloch, 1934 & $\mathrm{n}$ & 0 & 0 & 0 & 0 & 2 & 2 \\
\hline & Gymnodia quadristigma (Thomson, 1869) & $\mathrm{c}$ & 0 & 0 & 0 & 0 & 0 & 2 \\
\hline & Limnophora narona (Walker, 1849) & $\mathrm{c}$ & 0 & 1 & 0 & 0 & 5 & 7 \\
\hline & Musca domestica Linnaeus, 1758 & $\mathrm{c}$ & 7 & 3 & 5 & 0 & 0 & 0 \\
\hline & Muscina stabulans (Fallén, 1817) & $\mathrm{c}$ & 8 & 5 & 3 & 3 & 3 & 1 \\
\hline & Mydaea plaumanni Snyder, 1941 & $\mathrm{n}$ & 0 & 0 & 0 & 0 & 0 & 8 \\
\hline & Myospila obscura (Shannon \& Del Ponte, 1926) & $\mathrm{n}$ & 0 & 0 & 0 & 0 & 0 & 2 \\
\hline & $\begin{array}{l}\text { Neomuscina zosteris (Shannon \& Del Ponte, } \\
\text { 1926) }\end{array}$ & $\mathrm{n}$ & 0 & 0 & 0 & 0 & 2 & 0 \\
\hline & Neurotrixa felsina (Walker, 1849) & $\mathrm{n}$ & 1 & 1 & 0 & 10 & 0 & 4 \\
\hline & Phaonia trispila (Bigot, 1885) & $\mathrm{n}$ & 0 & 0 & 0 & 0 & 1 & 2 \\
\hline & Ophyra aenescens (Wiedemann, 1830) & $\mathrm{c}$ & 7 & 0 & 16 & 0 & 120 & 3 \\
\hline & Ophyra albuquerquei Lopes, 1985 & $\mathrm{n}$ & 1 & 0 & 0 & 0 & 0 & 0 \\
\hline & Ophyra chalcogaster (Wiedemann, 1824) & $\mathrm{n}$ & 1 & 2 & 3 & 0 & 0 & 0 \\
\hline & Psilochaeta chalybea (Wiedemann, 1830) & $\mathrm{n}$ & 0 & 2 & 5 & 2 & 2 & 9 \\
\hline & Psilochaeta chlorogaster (Wiedemann, 1830) & $\mathrm{n}$ & 0 & 2 & 0 & 4 & 0 & 0 \\
\hline
\end{tabular}




\begin{tabular}{|c|c|c|c|c|c|c|c|c|}
\hline \multirow[t]{2}{*}{ Family } & \multirow[t]{2}{*}{ Species } & \multirow[t]{2}{*}{ Status } & \multicolumn{2}{|c|}{$\mathrm{PG}$} & \multicolumn{2}{|c|}{ UP } & \multicolumn{2}{|c|}{ NR } \\
\hline & & & $\mathrm{CV}$ & $\mathrm{F}$ & $\mathrm{CV}$ & $\mathrm{F}$ & $\mathrm{CV}$ & $\mathrm{F}$ \\
\hline & $\begin{array}{l}\text { Psilochaeta pampiana (Shannon \& Del Ponte, } \\
\text { 1926) }\end{array}$ & $\mathrm{n}$ & 0 & 1 & 0 & 2 & 18 & 43 \\
\hline & Synthesiomyia nudiseta (Wulp, 1883) & $\mathrm{c}$ & 1 & 2 & 1 & 6 & 3 & 4 \\
\hline Sarcophagidae & Blaesoxipha sp. & & 0 & 0 & 0 & 0 & 0 & 1 \\
\hline & Helicobia aurescens (Townsend, 1927) & $\mathrm{n}$ & 0 & 0 & 0 & 0 & 0 & 2 \\
\hline & Microcerella erythropyga (Lopes, 1936) & $\mathrm{n}$ & 0 & 0 & 0 & 1 & 0 & 0 \\
\hline & Microcerella muehni (Blanchard, 1939) & $\mathrm{n}$ & 0 & 0 & 10 & 3 & 11 & 12 \\
\hline & Microcerella sp. & & 0 & 0 & 0 & 1 & 0 & 0 \\
\hline & Nephochaetopteryx cyaneiventris (Lopes, 1936) & $\mathrm{n}$ & 0 & 0 & 0 & 0 & 7 & 25 \\
\hline & Oxysarcodexia bicolor Lopes, 1946 & $\mathrm{n}$ & 0 & 0 & 0 & 1 & 0 & 7 \\
\hline & Oxysarcodexia culmiforceps Dodge, 1966 & $\mathrm{n}$ & 0 & 0 & 1 & 2 & 2 & 3 \\
\hline & Oxysarcodexia marina (Hall, 1938) & $\mathrm{n}$ & 0 & 4 & 0 & 0 & 1 & 0 \\
\hline & Oxysarcodexia paulistanensis (Mattos, 1919) & $\mathrm{n}$ & 26 & 39 & 28 & 31 & 39 & 43 \\
\hline & Oxysarcodexia terminalis (Wiedemann, 1830) & $\mathrm{n}$ & 0 & 2 & 0 & 0 & 1 & 1 \\
\hline & Oxysarcodexia thornax (Wiedemann, 1830) & $\mathrm{n}$ & 0 & 0 & 3 & 16 & 3 & 3 \\
\hline & Oxysarcodexia varia (Walker, 1836) & $\mathrm{c}$ & 4 & 12 & 14 & 17 & 26 & 26 \\
\hline & Peckia spp. & & 0 & 0 & 2 & 0 & 2 & 0 \\
\hline & Ravinia sueta (Wulp, 1895) & $\mathrm{n}$ & 5 & 18 & 2 & 12 & 1 & 12 \\
\hline & Sarcodexia lambens (Wiedemann, 1830) & $\mathrm{n}$ & 0 & 0 & 1 & 1 & 0 & 0 \\
\hline & Sarcophaga (B.) africa (Wiedemann, 1824) & $\mathrm{c}$ & 12 & 13 & 0 & 0 & 0 & 0 \\
\hline & Sarcophaga (L.) argyrostoma (R-D, 1830) & $\mathrm{c}$ & 0 & 3 & 0 & 0 & 0 & 1 \\
\hline & Sarcophaga (L.) crassipalpis (Maquart, 1839) & $\mathrm{c}$ & 3 & 7 & 2 & 4 & 0 & 2 \\
\hline & Sarcophaga (L.) koehleri (Blanchard, 1939) & $\mathrm{n}$ & 1 & 0 & 0 & 1 & 3 & 1 \\
\hline & Sarcophaga (L.) lanei (Townsend, 1934) & $\mathrm{n}$ & 0 & 0 & 0 & 1 & 0 & 1 \\
\hline & Tricharaea (T.) brevicornis (Wiedemann, 1830) & $\mathrm{c}$ & 1 & 6 & 0 & 0 & 0 & 0 \\
\hline & Tricharaea (S.) occidua (Fabricius, 1794) & $\mathrm{n}$ & 30 & 314 & 52 & 618 & 24 & 140 \\
\hline & Udamopyga percita (Lopes, 1938) & $\mathrm{n}$ & 0 & 0 & 0 & 1 & 0 & 3 \\
\hline Totals & & & 2173 & 658 & 4214 & 1077 & 5727 & 839 \\
\hline
\end{tabular}


